\title{
ПРОГНОЗИРОВАНИЕ ПЕТРОФИЗИЧЕСКИХ СВОЙСТВ РЕЗЕРВУАРА С ПРИМЕНЕНИЕМ НЕЙРОННЫХ СЕТЕЙ
}

Попович С.В.* Делия С.В. **, Смирнов В.Е.*, Чуприна О.В.*

(*- ООО "ЛУКОЙЛІ-ВолгоградНИПИжорнефть", ** - ООО "ЛУКОЙЛ-Нижневолжскнефть")

Резюме: Разработана новая модель геологического строения Алексеевского месторождения Волгоградской области на основе комплексной интерпретачии материалов сейсморазведки и ГИС с применением технопогий нейросетевого и петрофизического жоделирования разреза.

При детализации геологического строения небольших месторождений применение сейсморазведки 3D представляется неоправданньм. Для получения дополнительной информации о строении резервуара в последнее время осуществляется интерпретация данных сейсморазведки 2D с применением математидеского аппарата на основе искусственных нейроннњг сетей.

Эффективность атрибутного нейронного анализа опробована на примере Алексеевского месторождения в Левобережной части Волтоградской области. Нефтяные залежи здесь выявлены в терригенных бобриковских и карбонатньх турнейских отложениях. Результаты бурения и эксплуатации скважин свидетельствуют о неадекватности суцествуюшей модели геологического строения месторождения.

Для разработки модели месторождения средствами комплекса Petrel была построена 3D каркасная модель, подготовлен псевдо-сейсмический куб по данным сейсморазведки МОГТ-2D, выполнены нейросетевой прогноз и петрофизическое моделирование резервуара. Каркасная модель включала три стратиграфических интервала: тульский, бобриковский и турнейский. Для уменьшения влияния краевых эффектов добавлены верхняя и нижняя вспомогательные зоны, не приуроченные к стратиграфическим горизонтам.

При подготовке псевдо-сейсмического куба, ячейки 3D-грида каркасной модели заполнялись осредненными значениями сигналов с применением нелинейной интерполяцни (Kriging) в межпрофильном пространстве. Полученный 3D-грид со свойством амплитуд сейсмических сигналов конвертировался в псевдо-сейсмический куб, который использовался для расчета атрибутов, автоматического извлечения разломов и моделирования.

Для формирования обучающей выборки из комплекса ГИС были отобраны наиболее информативные для исследуемых разрезов методы каротажа, максимально дифференцирующие разрез по литолого-петрофизическим свойствам: ГК и плотностной ГГК. Гамма каротаж позволяет оценить глинистость разреза, пространственное распространение глинистых пластов и чистьг от глин песчаньх пластов для выявления покрышек в тульских и коллекторов в бобриковских отложениях. Плотностной каротаж использовался, в основном, для оценки пространственной изменчивости плотности карбонатных турнейских отложений и локализация областей разуплотнения.

На вход нейронных сетей подавались наборы сейсмических трасс и подготовленные каротажные кривые. В результате обучения нейронной сети были получены кубы естественной радиоактивности и плотности, которые использовались в дальнейшем как "тренд-свойства" при петрофизическом моделировании и интерполяция даннњх по скважинам в межскважинное пространство.

Петрофизическое моделирование выполнялось с использованием стохастического алгоритма Sequential Gaussian Simulation, учитывающего скважинные данные, входные распределения параметров, вариограммы и тренды свойств.

В качестве основного набора данных использовались исходные кривые ГК и ГГК, применение которых позволило исключить "отскоки" в значениях свойств, полученные в процессе обучения, а также уменьшить погрешность моделирования. Кубы естественной радиоактивности и плотности, полученные ранее с помощью нейронных сетей, были осреднены в ячейки грида и использовались как переменные для направленного пространственного моделирования. Применение такого метода позволяет выявить и учесть распространение неоднородностей параметров разреза в межскважинном пространстве, проследить зоны выклинивания и литологического замещения.

Выявленными связями между петрофизическими свойствами отложений по данным ГИС обоснован переход от кубов естественной радиоактивности и плотности к кубам глинистости, пористости. С учетом обоснованных граничных значений по глинистости и пористости, породы разделены на литотипы, выделены коллекторы, покрыпши и сформирован куб литологии, по которому подготовлены карты суммарных эффективных толшин коллекторов в бобриковских и турнейских отложениях.

Анализ атрибутов вариантности и меры неупорядоченности с использованнем процедуры Ant Tracking показал, что в разрезе турнейско-бобриковских отложений могут присутствовать малоамплитудные разрывные нарушения, не являющиеся экранами.

В результате применения технологии нейросетевого и петрофизического моделирования разреза, построена трехмерная геологическая модель месторождения, хорошо согласующаяся с данными бурения. Применение динамической интерпретации волнового поля обеспечило большую пространственную разрешенность записи по сравнению с исходными сейсмическими материалами.

Геологическая интерпретация куба литологии показала, что основное влияние на распределение залежей в бобриковских и турнейских отложениях имеют не разрывные нарушения, а латеральная изменчивость петрофизических свойств пластов-коллекторов, обусловленная литоло-фациальными закономерностями формирования пород. 